\title{
Nutrient status of wheat growing soils in Meerut district of Uttar Pradesh
}

\section{Rakesh Tiwari, Prabha Shankar Tiwari and Ashok Singh}

Received : 11.04.2020; Revised : 09.05.2020; Accepted : 27.05.2020

\section{MEMBERS OF RESEARCH FORUM:}

Corresponding author :

Prabha Shankar Tiwari, Krishi

Vigyan Kendra, Hastinapur, Meerut

(U.P.) India

Email: drpsteng@gmail.com

Co-authors :

Rakesh Tiwari and Ashok Singh, Krishi Vigyan Kendra, Hastinapur, Meerut (U.P.) India

\section{Summary}

A study was conducted on nutrient status of wheat growing soils in district Meerut Uttar Pradesh. The study was conducted in soil testing laboratory of Krishi Vigyan Kendra Meerut and soils were collected from farmer's field in the year 2017-18 and 2018-19. The analysis of soil samples shows that most of the soils of Meerut district are low to medium in organic carbon $(0.41 \%)$, low in available nitrogen $(210 \mathrm{~kg} / \mathrm{ha})$, medium in available phosphorus $(13.55$ $\mathrm{kg} / \mathrm{ha}$ ) and potash (195 kg/ha) and there is a need for a close monitoring of nutrient management and application of the fertilizer recommendations on the basic of STB (soil testing based) to enhance the wheat productivity.

Key words : Nutrient, STB, Monitoring, Productivity

How to cite this article : Tiwari, Rakesh, Tiwari, Prabha Shankar and Singh, Ashok (2020). Nutrient status of wheat growing soils in Meerut district of Uttar Pradesh. Asian J. Soil Sci., 15(1): 65-67 : DOI : 10.15740/HAS/AJSS/15.1/65-67.Copyright@2020: Hind Agri-Horticultural Society. 